\title{
TEORI KOMUNIKASI
}

Perspektif Feminis Dalam Media Komunikasi Film (Wacana Kritis Perjuangan Keadilan Gender Dalam Film "Three Billboard Outside") Oleh:

(1) Radita Gora Tayibnapis, (2) Risqi Inayah Dwijayanti

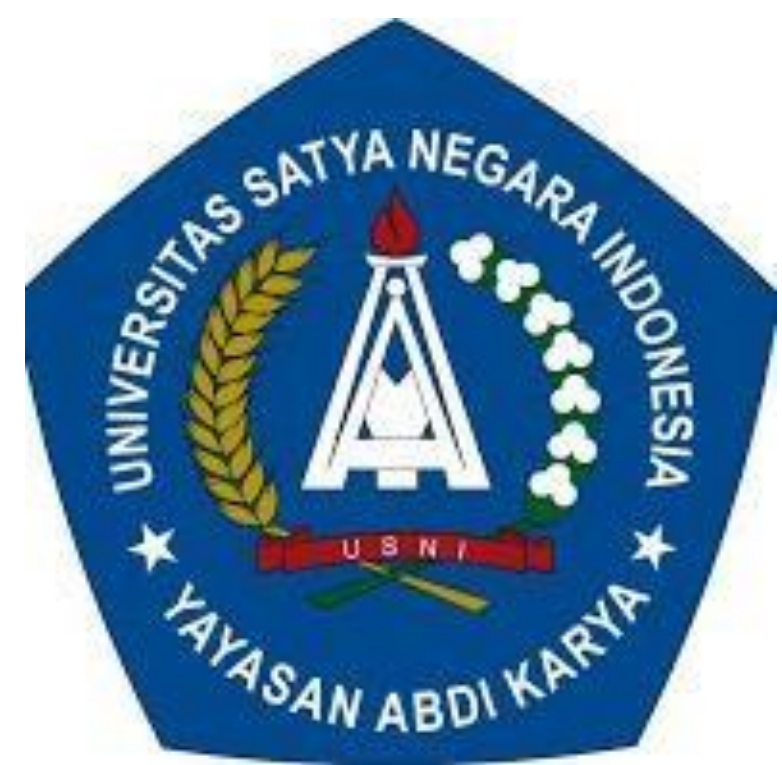

Disusun Oleh :

GANDA UMARYADI

180900015

FAKULTAS ILMU SOSIAL ILMU POLITIK

ILMU KOMUNIKASI

UNIVERSITAS SATYA NEGARA INDONESIA

2020 


\section{BAB I}

\section{A. Latar Belakang}

Feminisme memang tidak serta-merta mengarah pada filsafat. Feminisme erat kaitannya dengan gerakan politik yang memperjuangkan kesetaraan hak. Namun, konsep kesetaraan hak tidak lain muncul dari konsep liberalisme. Konseptualisasi feminisme banyak mengadopsi model filsafat modern seperti universalisme, individualisme, rasionalisme, dan humanisme. Konsep inilah yang ingin ditentang oleh feminisme karena menyingkirkan perempuan dari anggapan kemanusiaan yang utuh. Sebab itu perempuan menggunakan konsep yang sama untuk membentuk representasinya sendiri di dalam feminisme. Konsep feminisme mulai dirancang sedemikian rupa sehingga membuat perempuan berdiri sama tinggi dengan laki-laki.

Feminisme menyangkut bagaimana memosisikan subjek perempuan di dalam masyarakat, Selama ini perempuan telah diposisikan inferior dalam masyarakat. Perempuan dianggap sebagai The Other yang relasinya selalu menunggu untuk didefinisi dan dimaknai. Identitas perempuan selalu dilekatkan oleh konstruksi sosial. Begitu pula di dalam konsep modern, perempuan selalu menjadi subjek yang berlawanan dengan subjek laki-laki. Di dalam masa pencerahan subjek berada di dalam etika promethean dimana individu tunduk pada alam. Sehingga subjek dapat berubah dari dalam dirinya dan pengaruh lingkungannya. Subjek promethean dianggap dapat menguasai alam dan memiliki posisi yang vital. Keniscayaan subjek yang terpusat harus memiliki hubungan dengan yang lain (the other). Tetapi the other ini selalu diposisikan lebih rendah dan berada di luar kekuasaan.

Asumsi perempuan sebagai the other ditunjukkan ketika perempuan dianggap tidak berasio dan dibatasi aksesnya terhadap hak politik di ruang publik. Hal ini yang menyebabkan dibentuknya gerakan perempuan untuk kesetaraan hak politik, pendidikan dan ekonomi. Di sini pula dimulainya penyebaran kesadaran pembebasan perempuan.

Pada abad ke sembilan belas gerakan feminis liberal mulai membangun kesadaran bahwa perempuan harus memiliki hak pilih. Dengan memilih, perempuan dapat mentransformasi sistem dan struktur yang menindas. Suffragis (pembela hak suara perempuan) abad kesembilan belas berjuang bersama dengan gerakan abolisi dimana kaum budak kulit hitam menuntut kebebasan. Namun, abolisionis laki-laki cenderung tidak ingin menyangkutpautkan misinya dengan feminis kulit putih. Karena itu mereka membujuk feminis untuk memisahkan perjuangannya dengan perjuangan pembebasan kulit hitam. 
Feminisme sendiri yang berasal dari kata "Femme" (woman), berarti perempuan (tunggal) yang berjuang untuk memperjuangkam hak-hak kaum perempuan (jamak) sebagai kelas social. Tujuan dari feminism ini adalah keseimbangan interelasi gender. Dalam arti leksikal, feminism adalah gerakan wanita yang menuntut persamaan hak sepenuhnya antara kaum wanita da pria. Feminisme ialah teori tentang persamaan antara persamaan antara laki-laki dan wanita di bidang politik, ekonomi, dan social atau kegiatan terorganisasi yang memperjuangkan hak-hak kepentingan wanita. Feminis merupakan gerakan yang dilakukan oleh kaum wanita untuk menolak segala sesuatu yang dimarginalisasikan, disuborganisasikan, dan diendahkan oleh kebudayaan yang dominan. Baik dalam tataran politik, ekonomi, maupun kehidupan social lainnya. Dalam tradisi Barat sejak zaman Yunani dan tradisi Yahudi - Kristen sejak awal telah mengemuka pengertian-pengertian tentang "kejantanan"(kelaki - lakian) dan "Keperempuanan" yang mengonstruksi dan mempengaruhi ide-ide tentang laki-laki dan perempuan.

Ide-ide ini merupakan hasil pemikiran manusia, yang dikonstruksikan sejarahnya, pengalaman dan kebudayaannya. Kaum perempuan tidak terlibat dalam membentuk perkembangan filsafat dan ilmu pengetahuan, sehingga perempuan hanya menjadi bagian dari manusia kelas dua seperti dikemukakan oleh Simon De Beauvior. Berdasarkan ini, Plato kemudian memunculkan ide mengenai jiwa rasional yang menguasai dan mengatur badan yang memuat di dalamnya ide laki-laki yang mengatur perempua. (Lubis, 2015)

Dalam perspektif ini, peneliti melihat adanya ketidak seimbangan yang terjadi terhadap ketidak adilan gender yang terjadi terhadap kaum wanita dalam film "Three Billboard Outside". Menurut peneliti, tak sedikit film yang mengangkat tentang masalah kekerasan pada wanita, marginalisasi gender, dan juga pemojokan terhadap posisi perempuan yang lebih rendah dibanding laki-laki. Di satu sisi terjadinya kontradiksi antara perempuan dan masalah keadilan hukum. Hal ini yang terjadi pada film asal Amerika yang berjudul "Three Billboard Outside". Film besutan dari sutradara Martin McDounagh yang memenangkan Golden Globes 2018 sebagai kategori film drama terbaik ini selain mendapat aspirasi dari masyarakat luas, di satu sisi film ini menjadi masalah kontroversi bagi pihak hukum di Amerika, lantaran adanya kontradiksi terhadap persoalan penanganan masalah hukum di Amerika dan ketidaksetaraan gender. Dalam penelitian ini terdapat suatu kontroversi terhadap film ini persoalan sindiran terhadap masalah kesetraaan gender di Amerika yang seperti dilansir The Guardian, terkait representasi gender dan pengakuan terhadap kesetaraannya, Amerika masih menduduki peringkat ke 32 menyusul rendahnya representasi perempuan di parlemen, tingginya tingkat kekerasan terhadap perempuan.

Penelitian media feminism merupakan bidang penelitian yang kuat dalam penelitian budaya. Penelitian ini selama bertahun - tahun telah bergeser dari ketertarikan dalam 
mengkritisi streotip gender (penelitian penggambaran gender) ke melihat pada bagaimana penggambaran wanita dalam pemosisian gender.

Berdasarkan latar belakang dan permasalahan tersebut, maka dalam hal ini peneliti tertarik untuk meneliti tentang permasalahan Wacana gender dari aspek marjinalisasi posisi perempuan terkait kasus kekerasan yang menuntut keadilan dengan perspektif feminis melalui film Three Billboard Outside Ebbing, Missouri. Selain itu, permasalahan yang akan diteliti adalah berkaitan dengan representasi perempuan dalam film Three Billboard Outside Ebbing Missouri.

\section{BAB II}

\section{B. Konsep Pemahaman Teori}

Dalam penelitian ini, peneliti menggunakan teori serta tradisi kritis dalam pendekatan yang dilakukan, karena berdasarkan latar belakang terdapat kesenjangankesenjangan 
yang ada di masyarakat. Peneliti menggunakan perspektif kritis dengan kajian feminisme sebagai fokus utama dalam penelitian. Gender mempengaruhi cara kita berperilaku, cara kita berpikir, dan cara kita merasa dengan cara yang sering tidak terlihat oleh kita. lebih jauh, kaum feminis mengklaim bahwa masyarakat telah dibangun secara sosial dalam patriarkal.

\section{Tradisi Kritis}

Tradisi ini berangkat dari asumsi teori-teori kritis yang memperhatikan terdapatnya kesenjangan di dalam masyarakat. Proses komunikasi dilihat dari sudut pandang kritis. Komunikasi dianggap memiliki dua sisi berlawanan, dimana disatu sisi ditandai dengan proses dominasi kelompok yang kuat atas kelompok masyarakat yang lemah. Pada sisi lain, aktivitas komunikasi mestinya menjadi proses artikulasi bagi kepentingan kelompok masyarakat yang lemah.

Istilah teori kritis berasal dari kelompok ilmuwan Jerman yang dikenal dengan sebutan "Frankfurt School". Para teoritisinya mengadopsi pemikiran Marxis. Kelompok ini telah mengembangkan suatu kritik sosial umum, di mana komunikasi menjadi titik sentral dalam prinsip-prinsipnya. Sistem komunikasi massa merupakan focus yang sangat penting di dalamnya. Tokoh-tokoh pelopornya adalah Max Horkheimer, Theodore Adorno serta Herbert Marcuse. Pemikirannya disebut dengan teori kritis. Ketika bangkitnya Nazi di Jerman, mereka berimigrasi ke Amerika. Di sana mereka menaruh perhatian besar pada komunikasi massa dan media sebagai struktur penindas dalam masyarakat kapitalistik, khususnya struktur di Amerika.

Teori kritis menganggap tugasnya adalah mengungkap kekuatan-kekuatan penindas dalam masyarakat melalui analisis dialektika. Teori kritis juga memberikan perhatian yang sangat besar pada alat-alat komunikasi dalam masyarakat. Komunikasi merupakan suatu hasil dari tekanan antara kreativitas individu dalam memberi kerangka pesan dan kendala-kendala sosial terhadap kreativitas tersebut. Salah satu kendala utama pada ekspresi individu adalah bahasa itu sendiri. Kelas-kelas dominan dalam masyarakat menciptakan suatu bahasaa penindasan dan pengekangan, yang membuat kelas pekerja menjadi sangat sulit untuk memahami situasi mereka dan untuk keluar dari situasi tersebut. Kewajiban dari teori kritis adalah menciptakan bentuk-bentuk bahasa baru yang memungkinkan diruntuhkannya paradigma dominan. Hal itulah yang diungkapkan oleh Jurgen Habermas, tokoh terkemuka kelompok Franfurt School di era berikutnya.

Kajian ini memiliki beragam definisi mulai dari pergerakan untuk menyelamatkan hak-hak perempuan hingga perjuangan untuk menegaskan perbedaannya. Penelitian feminis lebih dari sekedar kajian terhadap gender. Feminisme berupaya untuk 
memusatkan teori terhadap pengalaman perempuan dan untuk membicarakan kategori-kategori gender dan sosial lainnya, termasuk ras, etnis, kelas, dan seksualitas. (Jhon \& Foss, 2009)

\section{Teori Feminisme}

Teori Feminis adalah suatu wilayah yang telah memberikan kontribusi penting dan orisinil terhadap pemikiran yang kontemporer. Keunikan yang ada dalam teori ini adalah ketegasan dan keterkaitannya tentang teori dan praktiknya antara publik dan privat. Tentang teori dan pengalaman yang mempunyai hubungan yang khusus dalam feminisme yang telah dikemas dalam suatu slogan "the personal is political". Feminisme sendiri yang berasal dari kata "Femme" (woman), berarti perempuan (tunggal) yang berjuang untuk memperjuangkam hak-hak kaum perempuan (jamak) sebagai kelas social. Tujuan dari feminism ini adalah keseimbangan interelasi gender. Dalam arti leksikal, feminism adalah gerakan wanita yang menuntut persamaan hak sepenuhnya antara kaum wanita dan pria.

Feminisme adalah suatu gerakan kritis terhadap simbol, ideologi dan sebuah kultur yang telah memperlakukan perempuan secara tidak adil. Adapun tujuan pokok dari teori feminisme sendiri adalah untuk memahami berbagai penindasan wanitta secara ras, gender, kelas dan piliha seksual dan bagimana mengubahnya yang terpenting dari teori ini adalah mengungkapkan nilai pribadi perempuan serta pengalaman yang dialaminya bersama dengan perjuangan yang telah mereka lakukan. Teori yang mnganalisis perbedaan seksual itu terbangun dalam setiap individu dan bagaimana ia dapat memberikan penjelasan tentang pengalaman dari berbagai perbedaan yang ada. Teori feminisme menfokuskan diri pada pentingnya kesadaran mengenai persamaan hak antara perempuan dan laki-laki dalam semua bidang.

Teori ini berkembang sebagai reaksi dari fakta yang terjadi di masyarakat, yaitu adanya konflik perbedaan kelas, konflik ras, dan yang utam oleh konflik gender. Feminisme mencoba untuk mendekonstruksi sistem yang menimbulkan kelompok yang mendominasi dan didominasi, serta sistem hegemoni di mana kelompok subordinat terpaksa harus menerima nilai-nilai yang ditetapkan oleh kelompok yang berkuasa. (Lubis, 2015)

\section{Feminisme Liberal}

Aliran Feminisme ini muncul pada abad ke-19. Pemikiran kelompok Feminisme Liberal berpendapat bahwa semua manusia baik laki-laki maupun perempuan telah 
diciptakan secara seimbang dan serasi dan seharusnya tidak akan ada penganiayaan dan penindasan antara keduanya. Dengan tokohnya Margaret Fuller (1810-1850), Anglina Grimke (1792-1873), dan Susan Anthony (1802-1906).

Teori ini mempunyai asumsi bahwa antara laki-laki dan perempuan mempunyai kekhususan yang secara otologis keduanya mempunyai kesetaraan dalam hakhaknya, tetapi teori Liberal ini ada hal yang tidak bisa disamakan antara laki-laki dan perempuan yaitu dalam hal reproduksi disini letak perbedaannya adalah dalam organ reproduksi perempuan yang membawa konsekwensi yang logis dalam kehidupan masyarakat.

Feminisme liberal banyak diadopsi oleh perempuan di dunia karena pengaruh kapitalisme. Kebebasan akan hak yang kini mendorong pemikir liberal maju secara linier dan tetap menekankan laju pertumbuhan linier.

Maksud dari teori ini perempuan tidak dibatasi dalam bekerja diluar rumah oleh karena itu perempuan dapat diintegrasikan secara total dalam semua peran dan organ repruduksi perempuan tidak menjadi pengahalang terhadap peran-peran perempuan.

\section{Feminisme Radikal}

Teori yang muncul abad ke-19 berasumsi bahwa perempuan tidak harus tergantung pada laki-laki baik kebutuhan seksualitasnya dan kebendaannya.

Teori ini juga telah menggugat lembaga-lembaga yang telah merugikan perempuan seperti lembaga patriarkhi. Yang intinya memfokuskan pada permasalahan ketertindasan perempuan yakni hak untuk memilih adalah simbol mereka. Kaum feminis radikal dan kultural telah menyatakan bahwa perbedaan antara seks atau gender mengalir karena sosialisasi history keseluruhan perempuan dalam masyarakat yang patriarkhi.

Tugas utama para feminisme radikal ini adalah menolak institusi keluarga baik maupun praktiknya, sehingga kebebasan perempuan tidak hanya perjuangan untuk mencapai kesetaraan hak saja, akan tetapi juga meliputi hal transformasi secara sempurna dalam ruang persahabatan dan hubungan kemanusiaan.

\section{Diskursus Teori Film dan Representasi Masyarakat Minoritas}

Dalam pemakanaannya sendiri, film dapat diartikan sebagai alat untuk menyampaikan berbagai pesan kepada khalayak melalui sebuah media cerita. Film juga merupakan medium ekspresi artistik sebagai suatu alat para seniman dan insan perfilman dalam rangkan mengutarakan gagasangagasan dan ide cerita. Secara esensial dan substansial film memiliki power yang akan berimplikasi terhadap komunikan masyarakat (Wibowo, 2006: 196). 
Dengan pemahaman atas diskursus film, maka sebenarnya bahwa film bisa merepresentasikan isu atau gagasan yang berkembang dalam masyarakat. Stuart Hall dalam buku Rachmah Ida "Budaya Popouler Indonesia : Diskursus Global/Lokal dalam Budaya Populer di Indonesia" melihat bahwa representasi dari praktik-praktik kehidupan sosial yang memproduksi budaya dan 'peristiwa'atau kejadian yang terjadi dalam masyarakat, dan gagasan itu dikenal dengan istilah sirkuit pusaran budaya.(Ida, 2017)

Menurut peneliti dalam penelitiannya terkait film "Three Billboard Outside" ini, sirkuit budaya menggambarkan hubungan-hubungan atau koneksi antara representasi dengan identitas, regulasi, konsumsi dan produksi. Kesatuan ini semua berkaitan dengan bagaimana makna diproduksi melalui penggambaran identitas dan peristiwa/kejadian yang berhubungan dengan regulasi atau aturan, berhubungan dengan konsumsi, berhubungan dengan proses produksi makna, dan pada akhirnya berhubungan dengan representasi yang ada di media massa dan demikian sebaliknya, dimana sirkuit budaya yang difokuskan oleh peneliti yakni mengkaji kajian feminisme dalam kesetaraan gender pada suatu film.

Dalam penelitian ini dijelaskan bahwa representasi melalui bahasa menjadi sentral bagi proses-proses ketika makna diproduksi. Sistem representasi meliputi objek (object), orang (people), dan kejadian atau peristiwa (event) yang berhubungan dengan seperangkat konsep-konsep atau mental presentations yang kita bawa dalam benak kepala kita. Tanpa itu kita tidak mampu menginterpretasikan dunia secara bermakna. (Ida, 2017)

Dapat dipahami bahwa representasi pada akhirnya menghubungkan antara makna dan bahasa terhadap budaya. Hal lebih lanjut mendeifinisikan bahwa representasi berarti menggunakan bahasa untuk berkata tentang sesuatu yang bermakna kepada orang lain atau dalam bahasa lain bahwa representasi adalah bagian esensial dari proses di mana makna diproduksi dan dipertkukarkan diantara anggota-anggota dari sebuah budaya yang memfokuskan pada kajian feminisme yang ada dalam film ini.

\section{BAB III}

\section{Metode Penelitian}

Dalam penelitian ini, peneliti menggunakan metode penelitian metode Kualitatif dengan jenis pendekatan Penafsiran Teks. Pada pendekatan Hermeneutik pada dasarnya berhubungan dengan bahasa. Menurut Peneliti, hermeneutik merupakan cara untuk 'bergaul' dengan bahasa. Bahasa menjelmakan kebudayaan manusia. Bahasa adalah medium yang tanpa batas, yang membawa segala sesuatu di dalamnya tidak hanya kebudayaan yang telah disampaikan kepada kita melalui bahasa, melainkan juga segala sesuatu tanpa ada kecualinya sebab segala sesuatu itu sudah termuat dalam lapangan 
pemahaman. Bahasa adalah perantara yang nyata bagi hubungan umat manusia. (Sumaryono, 2015)

Peneliti menggunakan metode Kualitatif dalam penelitian ini, dengan mempertimbangkan aspek-aspek asumsi ontologis, epistemologis, aksiologis.

Paradigma yang digunakan dalam penelitian ini adalah, Paradigma Kritis Feminisme, paradigma ini beranggapan bahwa realitas yang kita lihat adalah realitas semu yang telah terbentuk dan dipengaruhi oleh kekuatan sosial, politik, budaya, ekonomi, etnik, nilai gender, dan sebagianya, serta telah terkristalisasi dalam waktu yang panjang. Realitas sosial bukan apa adanya dan netral, pasti ada masalah dibaliknya.

Paradigma kritis hadir sebagai reaksi dari kelemahan paradigm konstruktivis yang dianggap kurang sensitive pada proses pertukaran makna yang terjadi secara historis maupun institusional. Seperti ditulis A.S. Hikam pandangan konstruktivisme masih belum menganalisis faktor-faktor hubungan kekuasaan.

Paradigma ini berangkat dari ajaran marxisme dan dikembangkan oleh tokoh-tokoh mazhab Frankfurt. Paradigma ini tidak hanya mengkritik ketidakadilan sistem yang dominan tetapi juga mengubah sistem dan struktur tersebut menjadi lebih adil. Bagi paradigma kritis tugas ilmu sosial adalah justru melakukan penyadaran kritis masyarakatterhadap sistem dan struktur sosial yang cenderung "mendehumanisasi” atau membunuh nilai-nilaikemanusiaan.

Menurut Muhammad Fahmi Akbar,dalam paradigma kritis, positivisme dan empirisme tidak adil karena ilmu sosial yang bertindak tidak memihak, netral, objektif serta harus mempunyai jarak. Ini merupakan suatu sikap ketidakadilan karena dapat melanggengkan status quo. Oleh karena itu, paradigma ini menolak hal tersebut.

Paradigma kritis mengharuskan adanya bentuk subjektifitas, keberpihakan pada nilainilai tertentu -terutama membela kaum lemah, golongan yang tertindas dan kelompok minoritas.

Menurut Oktavianus Forensamidi, paradigma kritis. Paradigma ini berperan dalam proses membangkitan kesadaran kritis serta perilaku konstruktif terhadap realitas yang dihadapi. Olehkarena itu, verifikasi kebenaran tidak diukur oleh rumus ataupun angka, tetapi melalui praktis yang berupa aksi masyarakat.

Feminisme merupakan cabang dari teori kritis tetapi dari perspektif gender yaitu ada ketimpangan karena ketidakadilan gender. Menurut Mulyadi Saputra, Feminisme berdasar pada asumsi bahwa gender merupakan konstruksi sosial yang didominasi oleh pemahaman yang bias laki-laki dan menindas perempuan. Feminisme secara umum menantang asumsi 
dasar masyarakat dan mencari alternatif pemahaman yang lebih membebaskan, yaitu pemahaman yang meletakkan wanita dan pria dalam posisi yang seimbang.

Feminisme secara garis besar dapat diklasifikasi menjadi dua golongan, yaitu feminisme liberal dan feminisme radikal. Feminisme liberal lebih kepada paham paham demokrasi liberal, yaitu bahwa keadilan mencakup juga jaminan terhadap kesamaan hak bagi semua individu. Sedangkan feminisme radikal, lebih kepada melihat persoalan tidak sebatas pada hak yang bersifat publik. Oleh karena itu, jika feminisme liberal beranggapan bahwa masalah gender dapat diatasi dengan distribusi hak secara adil, maka bagi feminisme radikal hal ini tidak menyelesaikan persoalan. Feminisme radikal mempermasalahkan antara lain tubuh serta hak-hak reproduksi, seksualitas (termasuk lesbianisme), seksisme, relasi kuasa perempuan dan laki-laki.

\section{Konsep Dasar Penelitian Kualitatif}

Istilah penelitian kualitatif menuurut Kirk dan Miller (1986:9) pada mulanya bersumber pada pengamatan kualitatif yang dipertentangkan dengan pengamatan kuantitatif. Penelitian kualitatif perlu kiranya dikemukakan oleh beberapa definisi. Pertama, Bodgan da Taylor (1975:5) mendefinisikan metodologi kualitatif sebagai prosedur penelitian yang menghasilkan data deskriptif berupa kata-kata tertulis atau lisan dari orang-orag dan perilaku dapat diamati. Kedua, Kirik dan Miller (1986:9) mendefinisikan bahwa penelitian kualitatif adalah tradisi tertentu dalam ilmu pengetahuan social yang secara fundamental bergantung dari pengamatan pada manusia baik dalam kawasannya maupun dalam peristilahannya. Dalam penelitian kualitatif merupakan penelitian yang memanfaatka wawancara terbuka untuk menelaah dan memahami sikap, pandangan, perasaan, dan perilaku baik individu maupun sekelompok orang. (Moeleong \& Prof., 2005)

Dalam menggunakan metode penelitian kualitatif, penulis menganalisis data secara induktif, analisis data secara induktif ini digunakan karena beberapa alasan, yakni :

1. Proses induktif lebih dapat menemukan kenyataan-kenyataan jamak sebagai yang terdapat dalam data.

2. Analisis induktif lebih dapat membuat hubungan peneliti - responden menjadi ekspilist, dapat dikenal, dan akuntabel.

3. Analisis demikian lebih dapat menguraikan latar secara penuh dan dapat membuat keputusan-keputusan tentang dapat tidaknya pengalihan pada suatu layar lainnya.

4. Analisis induktif lebih dapat menemukan pengaruh bersama yang mempertajam hubungan-hubungan. 
5. Analisis demikian dapat memperhitungkan nilai-nilai secara ekspilist sebagai bagian dari struktur analitik.

(Subagyo, 2004)

\section{Teknik Pengumpulan Data}

\section{Teknik observatif}

Penelitian dilakukan dengan mengamati fenomenologi yang berhubungan dengan penelitian yang dilakukan oleh penulis.

\section{Teknik selektif}

Penulis mengumpulkan bahan yang terkait fenomenologi feminisme yang terjadi di film "Three Billboard Outside" yang menggunakan sosok perempuan sebagai pusat dari jalan cerita yang bersangkutan.

\section{Pustaka}

Mencari dan mengumpulkan tulisan - tulisan buku, jurnal - jurnal, dokumen online.

Studi kepustakaan ini dilakukan untuk memperoleh data sebagai analisa untuk menentukan konsep feminism dalam sebuah buku.

\section{E. Analisis data}

1. Mengidentifikasi data yang merupakan konsep feminism pada beberapa buku atau penelitian tersebut. Pada tahap ini, peneliti membaca secara berulang ulang buku tersebut dan mendeskripsikan apa yang dilihat pada saat membaca. Peneliti baru mereview tentang informasi yang diperolehnya.

2. Menganalisis pemberdayaan feminism dalam diskursus teori berdasarkan tradisi kritis pada buku Teori Komunikasi. Di tahap ini, peneliti memilih segala informasi yang diperoleh. (Jhon \& Foss, 2009)

3. Evaluasi semua review yang sudah dianalisa, sesuaikah dengan rumusan masalah pada penelitian ini. Pada tahap ini, peneliti mengevaluasi hasil yang telah dianalisis dengan rumusan masalah, apakah tujuan ini sudah tercapai atau belum.

4. Membuat kesimpulan berdasarkan data yang sudah dianalisis. Pada tahap ini peneliti membuat kesimpulan dari apa yang di lakukan pada tahap pertama, 
kedua, dan ketiga, apakah data yang di anilisis sudah benar-benar sesuai dengan tujuan penelitian.

\section{BAB IV}

\section{KESIMPULAN}

Berdasarkan pembahasan yang dilakukan oleh peneliti di atas terkait kajian feminisme dalam film Three Billboard Ebbing yang juga dianalisa berdasarkan hasil penelitian yang dilakukan oleh peneliti, menurut peneliti terlihat bahwa wacana yang ingin dibangun oleh sutradara melalui film Three Billboard Ebbing, Missouri adalah mengenai ketidakadilan perlakuan aparat hukum dalam kasus kekerasan dan penindasan perempuan. Sehingga wacana yang dibangun adalah tentang keberpihakan hukum terhadap kaum laki-laki dan memarjinalkan posisi perempuan. Kesimpulan yang dapat di tarik oleh peneliti di penelitian ini dalam konteks representasi gender adalah, perempuan direpresentasikan sebagai pihak yang tertindas dan terkucilkan sehingga perempuan membangun identitas yang menyimpang dari feminin atau sebagai wanita yang lemah, melainkan memposisikan perempuan sebagai posisi kekuatan militantan yang tidak ingin menunjukkan posisi yang lemah, melainkan menunjukkan posisi yang kuat meski dengan mengabaikan kelas sosial. Dalam representasi feminis yang dilihat oleh peneliti disini adalah representasi liberal yang menuntut adanya kesetaraan gender dengan laki-laki di mata hukum. Kemudian 
adanya pandangan pergerakan perempuan untuk menuntut adanya kelemahaman dan juga tuntutan dalam keberpihakan hukum terhadap keberadaan perempuan yang dinilai tumpul terhadap perempuan

\section{DAFTAR PUSTAKA}

Eriyanto. (2011). Analisis Wacana (Eriyanto (ed.)). LKIS.

Ida, R. (2017). Budaya Populer Indonesia : Diskursus Global/Lokal dalam Budaya Populer Di Indonesia (R. Ida (ed.)). Airlangga Universtiy Press.

Jhon, S. W. L., \& Foss, K. A. (2009). Teori Komunikasi (S. W. L. John (ed.); 9th ed.). Salemba Humanika.

Lubis, D. A. Y. (2015). Pemikiran Kritis Kontemporer (D. A. Y. Lubis (ed.)). PT. Rajawali Pers. Moeleong, L. J., \& Prof. (2005). Metodelogi Peneltian Kualitatif (P. D. L. J. M. M.A (ed.); Revisi). PT. Remaja Rosdakarya.

Subagyo, S. P. J. (2004). Metode Penelitian Dalam Teori Dan Praktik (P. J. S. SH (ed.)). PT. Rineka Cipta. 
Sumaryono,

E.

Hermeneutik:

Filsafat

(E.

(2015).

Revisi).

Kanisius.

Sebuah Metode

Sumaryono (ed.); 